\title{
THE CONCEPT OF ZIKR AND TAFAKKUR -BASED EDUCATION IN IMPROVING THE MORALITY OF THE NATION
}

\author{
A. Fatoni ${ }^{1}$, Deni Lesmana ${ }^{2}$ \\ Universitas Raden Intan (UIN) Lampung ${ }^{1}$, STEBI Global Mulia Cikarang ${ }^{2}$ \\ aa.fatoni99@gmail.com ${ }^{1}$, denilesmana.nuha@gmail.com ${ }^{2}$
}

\begin{abstract}
The various verses of the Quran explain that zikr and Tafakkur are always related. They should have become the spirit of the education system so that the graduates could possess a balanced zikr and Tafakkur. On the contrary, education is more focused on the development of knowledge. The dichotomy of knowledge affects education where ideally Islamic education includes zikr and Tafakkur education. Therefore, the integration of zikr and Tafakkur is something important, urgent, and beneficial for the improvement of the nation's morality.

The purpose of this study is to ensure the importance of the concept of zikr and Tafakkur in the perspective of the Qur'an by providing thought on the importance of the integration of zikr and Tafakkur in Islamic education so that it could be the basis for the development of Islamic education. The approach used in this study was the qualitative approach by employing the library research method. The integration of zikr and Tafakkur in Islamic educational institutions can be realized if the Qur'an is made as to the main base of knowledge source by researching, understanding, and deepening the science and technology based on Qur'an.
\end{abstract}

Key Words : Concept, Zikr, Tafakkur, Education ,Morality 


\section{INTRODUCTION}

Moral degradation is a concern to all nations, both developed countries, and developing countries because moral degradation can interfere with comfort and order. Moral degradation is one of the social problems that often occur in society such as promiscuity, pornographic videos, social violence, narcotics abuse, alcoholism, student brawls, inter-tribal brawls, corruption, and other criminal acts.

According to Daradjat Zakiah (1977,p.9), the moral is very important for everyone. Considering its importance, there is an Arabic poet who revealed that the size of the good and bad of a nation depends on the moral of the nation. If the nation is morally destroyed, then the nation will also be destroyed.

The simplistic view assumes that the decline in students' morals and ethics is due to the failure of religious education at schools. It must be admitted to a certain extent that religious education has certain weaknesses, ranging from the very short learning duration, too much theoretical material, the learning approach that is focused on the cognitive aspect rather than the affective and psychomotor skills. Faced with various obstacles and problems, religious education is not or is less functional in shaping the character, moral, and even personality of students. (Azyumardi Azra, 2002,p.178)

Moral values are all values related to the concepts of good and bad. Moral values will determine whether someone is guilty or not through the extent of responsibility and the resulting morality. Humans with good morality can be judged by the behavior which is a manifestation of morals and reason.

The humans' reasoning ability in understanding their environment is a basic potential that enables them to think. Human is a creature who is equipped with curiosity. Curiosity is what drives to better understand, know, and explain what happens to nature, and try to find the solutions in solving problems.

\section{THEORETICAL BASIS}

The word zikr has many meanings. According to Sa'id ibn Jubair, anyone who obeys Allah remembers Allah. According to Ibn At-Thaillah al-Sakarandi, zikr is breaking away from neglect by always presenting the heart to al-Haqq (Allah). Another opinion says that zikr is repeating the name of Allah by heart or oral. This can be done by remembering the name of Allah, His nature, His laws, His actions, or other similar actions. Zikr can also be in the form of praying, remembering His apostles, His prophet, His wali, people who are close to Him, and it can also be a mean to get close to Him through certain means and actions such as reading, remembering, singing, lecturing, and storytelling. (Ibn AtThaillah al-Sakandari, 2013,p.29)

The result of research conducted by Comstock, as contained in the Journal of Chronic Diseases (Comstock: 1972), states that those who carry out religious activities regularly by praying and zikr, have a lower risk of death from coronary heart disease by 50\% while the death from emphysema (lung inflation) is 56\% lower, deaths from hepatic cirrhosis (hardening of the liver) are $74 \%$ lower, and death from suicide are $53 \%$ lower.

Zikrullah (remembering Allah) is a noble practice in the sight of Allah SWT. It differentiates people who are loved by Allah and those who are hated by Him. People who like to zikr to Allah are lifted to a commendable place. 
According to experts, in the Quran, the reason is never mentioned in the form of a noun, but it is always in the form of a verb. The reason is the power of thinking (human intellectuals who have a problem-solving capacity) although any decision made by humans is made by heart, not by reason. (Ahmad Mubarok, 2010,p.186).

Our education is currently focused on the development of the left brain and only gives birth to a split personality. Education must be able to build whole human resources (holistic) integratively and be able to develop in a balanced manner of all the potential possessed which cover the mind, emotions, body, and spiritual. the education results show that, of all the potentials, the spiritual potential is the basis and core of human life.

Every educational unit must always be connected to the greatness of Allah the Almighty through zikr to Allah (Zikrullah) because there is a warning for educational institutions that neglect the aspect from zikr to Allah SWT. As stated in the hadith:

Meaning: "It is not a group of people sitting in an assembly, while they do not remember Allah Azza wa Jalla and do not recite to the Prophet but the assembly will be the remorse for them on the Day of Judgment. (Riwayah Ahmad and Ibnu Hibban)

In another hadith, it says:

"It is not a group of people sitting in an assembly, then they are dispersed without remembering Allah Azza wa Jalla but they are dispersed as carcasses of himar, and the assembly will become regret for them on the Day of Judgment."'(Riwayah by Abu Daud, Ibn Sunny, and Al-Hakim)

(Burkhardt, 1993: 48) states that zikr has a subjective dimension of one's religiosity. Spirituality provides space for humans to feel more important and meaningful to achieve a closer connection to Allah. In this context, the meaning of spiritual education in Islam is the process of approaching the divine presence to attain ma'rifatullah. Ibn 'Atha'illah al-Sakandary states that your closeness to Allah is your closeness to His ma'rifatullah. (Ahmad bin 'Ujaibah, 2005,p.295)

According to (Annemarie Schimmel, 2003,p.204), understanding the spiritual life is an expectation to obtain a satisfaction of souls and do not ask for worldly desires. Allah is the sole purpose of all prayers. Certain Sufis use prayers where the practices similar to the recitation of magical mantras. The existence of spiritual education is based on the belief that educational activities are the form of worship to Allah the Almighty through remembering (zikr).

The formula for forming spiritual power is that those who have the power of faith will develop patience. Patience is useful for controlling lust. Controlling lust will cause order. Order will give rise to power and strength. That strength is called spiritual power.

\section{RESEARCH METHODOLOGY}

This study employed a literature study (literature research). It employed the Library Research Method through the descriptive analysis techniques or qualitative analysis techniques (content analysis) by collecting data or materials that are related to the theme of the discussion and the problems which were taken from library sources. The data were then analyzed using the Maudhu'i method (thematic interpretation) which is a method of interpretation that explains the content of the verses of the Quran and the authentic hadith based on the theme or a certain topic. According to the opinion expressed by Abdul Hayyi al-farmawi, 
the pattern of interpretation is by gathering verses of the Quran that have the same purpose in the sense of the topic and then arranging them based on the period and background of the verses, then explanations, descriptions, comments on and the points of law contents are given.

This study employed the qualitative approach which is an approach inspired by the naturalistic paradigm (naturalistic inquiry). The approach is diametrically different from the positivistic paradigm (Jillian A Tullis Owen, 2008: 547). Epistemologically, the qualitative paradigm that is inspired by the naturalistic paradigm demands that the studied object should not be released from its context, or at least the studied object has a particular focus or accentuation without eliminating the context (Yonna S Lincoln and Egon G Guba, 2010,p. 28).

\section{DISCUSSION}

The reasoning is a function of reason. Through reasoning, humans use their minds to understand the nature of things. The essence of everything is truth and the true truth is Allah. Through reasoning, people get to know God and try to get closer to Him. The reasoning is the beginning of the journey of worship. Without reasoning, worship becomes worthless. The reasoning is the power of Tafakkur to understand something in which there is a possibility that the understanding obtained by reason can be wrong or correct.

The essence of zikr is the presence of the heart which should be the main goal for the perpetrators. They must strive to realize it, think of the meaning of the zikr, and understand the meaning of it. While doing so, they will be led to the peace of heart which in turn, will bring comfort and peace.

\section{a. The Concept of Zikr in Islamic Perspective}

Zikr is a practice that can invite the love and pleasure of Allah the Almighty. One way for a person to obtain the attention of the God is through zikrullah because one of the benefits of the faith is a lot of zikr to Allah by remembering the creator of the universe with his heart or mouth and the better with both.

Zikr means remembering Allah by saying and praising His name. Zikr is a prescribed obligation. Allah commands His faithful servants to zikr. Many of His verses command us to do zikr that is to remember Allah, to think of his creation, and to fill the heart and mouth with the praises to Him. As stated in the Holy Quran:

Meaning: O you who have believed, remember Allah with much remembrance. And exalt Him morning and afternoon (Surah AL-Ahzab: 41-42).

In the Quran, zikr should be done abundantly. Unlike zikr, hajj, umrah, zakat, or prayers are not required to be done over and over. Zikr is not bound by time and place. It can be done wherever and whenever as stated in the Holy Quran:

Meaning: Who remember Allah while standing or sitting or [lying] on their sides and give thought to the creation of the heavens and the earth, [saying], "Our Lord, You did not create this aimlessly; exalted are You [above such a thing]; then protect us from the punishment of the Fire (Surah Ali Imran: 191)

\section{b. The Concept of Reasoning in the Islamic Perspective}

In al-khawathir, sheikh Muhammad Mutawalli al-Syarawi says the reason is a measure used by humans to choose something that is considered better and better guarantees the future of self and their family. Through reasoning, according to James Allan, one can make choices. In social psychology, scientists define 
reasoning as the most important part that distinguishes humans from animals, plants, and inanimate objects. Through reasoning, humans can distinguish between something useful and worthless, between halal and haram, and between the positive and the negative. Thus, they can choose those that are appropriate and be responsible for the choices. (Ibrahim Elfiki,2013,p. 3)

Many people strongly believe that the power of positive reasoning can bring people to succeed in achieving their goals. There is no doubt that the power of Tafakkur (reasoning) will bring people to succeed in achieving their goals. Those who can direct their Tafakkur are always in a positive direction. It is believed that the result is a positive life.

Humans are the most perfect creations of Allah. It is shaped by life, knowledge, values, and beliefs that give birth to attitudes. Therefore, more than $90 \%$ of our attitudes are spontaneous that occurs without logical consideration. A person's attitude often occurs because of habits and outside influences (Ibrahim Elfiki, 2015,p.37).

According to Dafid J. Schwartz, the way we think is seen through the way we act. Attitude is a mirror of the mind. Attitudes reflect Tafakkur and it is not only seen but heard. (Dafid J. Schwartz, 2011,p. 234).

According to expert opinions, the mind can affect attitude. If someone thinks positively, it will result in positive attitudes and if they think negatively, it will result in negative attitudes. Therefore, one must think positively because positive Tafakkur are mental attitudes that involve the constructive process of thought, words, and images for the development of the mind. The reasoning can affect the results as stated by the experts that the mind affects the results. It can be seen in the following chart (Ibrahim Elfiki: 2015,p.215)

\section{c. Zikr and Tafakkur -based Education in Improving the Morals of the Nation}

Instilling the education of Islamic values starts from the family environment. After the Tawheed (monotheism) lessons have been firmly planted in a child, morals, skills, and all matters related to life are taught. Therefore, moral and spiritual education is very important for the development of good morality in a person to produce a generation of people who possess good morality. If children are familiarized with good behavior early on, they will get used to it until they grow up.

\section{d. The concept of Zikr and Tafakkur -based Education}

Al Attas in his proposal "Islamization of Science" reveals how the curriculum influences individual behavior. He states that the educational curriculum would form a paradigm of how someone views things (worldview). The paradigm will unconsciously adhere to the element of values through the received knowledge.

The formation of a national education curriculum based on zikr and Tafakkur can create an educational climate or an environment that is closely linked to exemplary and honesty. Of course, family supports and individual awareness contribute to supporting and strengthening the creation of good personalities. However, all of it depends on the existence of strong moral or religious values in each individual as a manifestation of the formation of the zikr and Tafakkur educational system. 


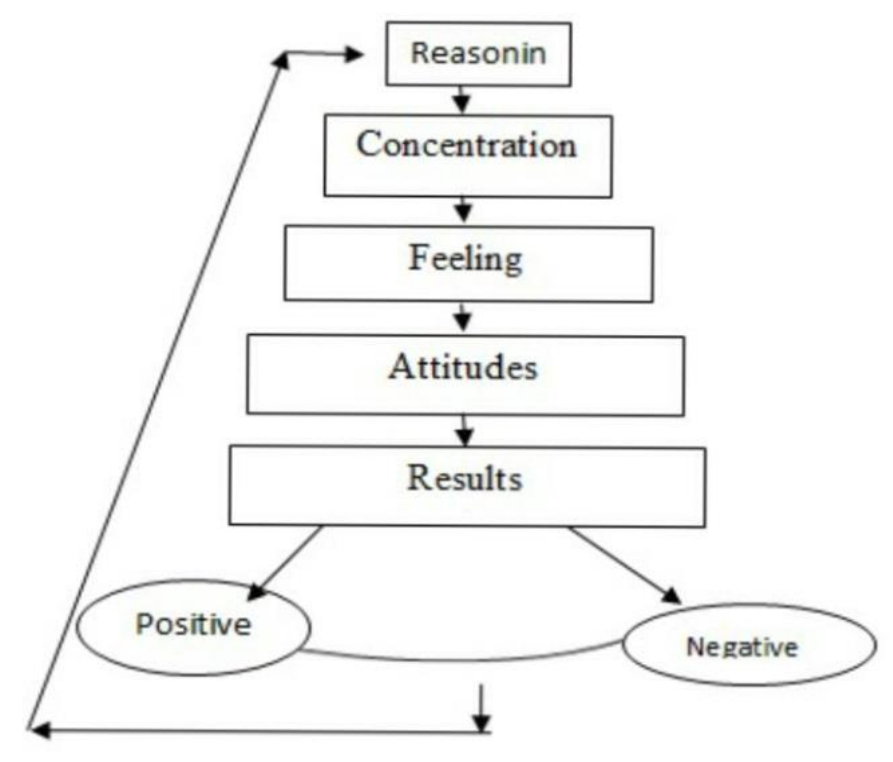

The output of the integration of zikr and Tafakkur can be felt and proven through good moral changes such as from an unstable soul into a calm soul, from a hard-headed person into a person who can receive advice. This condition shows a better moral formation. Another thing that needs to be emphasized in the moral formation of a nation is the cultivation of commendable qualities. A good

Muslim is a person who tolerates differences and dislikes violence, hostility, revenge, hatred, or kindling a fire of conflict to others, especially to fellow Muslims.

The students with high intellectuals because of zikr and Tafakkur will be the intellectual Islamic figures. In the following description, the researcher will explain a concept to improve morality through zikr and Tafakkur.

First, continuous and programmed habit. The moral development of the nation's children can be done through the development of educational institutions. If the fostering of religious culture in educational institutions which usually starts with the planting of religious values is continuously programmed, in turn, it will produce humans with abundant achievements. If it is not created and accustomed, the religious culture will not be realized. The improvement activities can foster human intelligence, faith, achievement that can benefit themselves, society, and nation.

Second, cultivate a religious culture. Education is the process of internalizing culture into a person and society to make them civilized. Education is not only a means of transfer of knowledge but more broadly, as a means of culture and distribution of values (inculturation and socialization). Religious education is not only limited to aspects of knowledge, but also includes the formation of religious attitudes, behaviors, and experiences. Therefore, the formation of religious attitudes, behaviors, and experiences is not only done by religious teachers or lecturers but also needs to be done by teachers or lecturers in other fields of study so that they will be formed and embedded by people who are experts in zikr and Tafakkur.

Third, instill the attitude of ikhsan. Instilling an attitude where someone is always feeling watched by God is the highest form of zikr. A person will always aware and leave something immoral if he feels that he is always seen by Allah the Almighty. There will be an attitude of shame towards God when someone commits immoral acts because of the feeling of always being monitored and witnessed by Allah the Almighty.

Fourth, instill honest culture. Honesty is the source of all forms of goodness and lies are the origin of all kinds of badness and sin. Honest behaviors 
reflect one's faith, morals. The cases of corruption, collusion, and nepotism are born because of dishonesty. If honest culture is not possible, immoral behavior will occur because honesty starts from the heart, words, and deeds. Someone whose act controlled by the deepest heart filled with zikr will always remember his God and try to control the despicable attitudes. Someone who has good reasoning will think a thousand times before showing bad attitudes. Zikr and Tafakkur cannot be separated like two different sides of a coin in instilling an honest culture. Honest culture must be implemented not only through words but also actions because honesty is the main foundation

\section{CONCLUSIONS}

Based on the results of the study, it can be concluded that:

a. The integration of zikr and Tafakkur, based on the perspective of the Quran, is a fundamental thing and cannot be separated because it is one of the pillars of life. Remembering Allah can be done verbally, by heart, and coupled with thinking by contemplating and understanding everything in the sky and on earth. A solemn zikr will stimulate the brain to concentrate and be more focused on thinking.

b. The implication of the concept of the integration of zikr and Tafakkur on the development of Islamic education is a modern educational concept that is built based on divinity.

c. The concept for the formation of moral based on zikr and Tafakkur is as follows:

1) Continuous and programmed habits.

2) Cultivating a religious culture.

3) Instilling the attitude of $i k h s a n$ which is to instill an attitude that is always feeling watched by Allah.

4) Instilling an honest culture because honesty is the source of all forms of goodness.

5) Creating religious conditions in educational institutions

\section{REFERENCES}

Abdul Qawi al-Mundziri, Mukhtasar Shahih Muslim. Solo:Insan Kamil,2012.

Abu Azmi Azizah. Bagaimana BerTafakkur Islam. Solo: Intermedia,2004.

Abuddin Nata, dkk., Konsep Ilmu Agama \& Ilmu Umum. Jakarta: PT Raja Grafindo Persada, 2005.

Ahmad Mahmud Sulaiman, Tuhan dan Sains (terj. dari Scientific Trend in The Al-Qur'an oleh Satrio Wahono. Jakarta : Serambi, 2001.

Ahmad Mubarok, Meraih bahagia dengan Tasawuf. Jakarta: Dian Rakyat,2010.

Abu al-Fida' Isma'il ibn Katsir,Tafsir al-Qur'an al-Adzim, Jilid II. Tahqiq:

Mustafa al-Sayyid Muhamad et.al, Kairo :Mu'assasah Qurtubah, 2000.

Abu Dawud, Sunan Abu Dawud. Beirut : Dar al-Kutub al-A'rabi,tt.

An-Nawawi, Al-Adzkar. Bandung : PT.Al-Ma'arif,1984.

Antonio Damasio, Emotion,Reason,an the Human Brain, Terj. Yudi Santoso, Memahami kerja otak. Yogyakarta: Baca, 2009.

Edward E. Smith, Psikologi Kognitif : Tafakkur an dan Otak, Yogyakarta : Pustaka Pelajar, 2014.

Harun Yahya,Deep Thinking:Bagaimana Seorang Muslim BerTafakkur , Jakarta: Robbani Press, 2001.

Ibnu At-Thaillah al-Sakandari, Zikir Penentram Hati, Jakarta: Zaman, 2013. 
| Aqmarina Bella Agustin ${ }^{1}$, Sukiman ${ }^{2}$

John C. Maxwell, Thinking for a Change. Batam:Karisma Press,2004.

Joseph Murphy,Keajaiban Kekuatan Tafakkur an, Jakarta: PT. Serambi Ilmu Semesta, 2015.

Nashir Fahmi, Spiritual Excellence, Depok :Gema Insani, 2011.

Sayyid Qutub, At-Tashawwurul-Fanniy Fil Qur'an,Qahirah: Darusy-Syuruq, 2004. 